\title{
新潟県にみる酒造労働力とその対策
}

\section{内 山幸二}

最近，と又に深刻化している酒造従業員の高齢化や人 材不足は, わが国の社会满造全体と大きく関わっている 問題だけに，打開策が難しい。

そこで，新潟県の出稼者実態調査に更に二，三の凟料 を加えて私見を述べ，今後の参考に供することとした。

\section{1. わが国の年令及び就業構成と酒造従業員}

総務庁統計局が発表した昭和 60 年の国勢調查による と全国の 65 歳以上の高壯者が初めて全人口の $10 \%$ を 超总，四世帯に一世带はこうした年配者が同居している ことが，明らかになった。また就業構成をみると 15 歳 以上の働く人は 5,822 万人, 第 1 次, 第 2 次, 第 3 次の 各産業部門別ではほぼ 1 対 3 対 6 の割合になっている。 一力, 日本杜氏組合連合会資料によると杜氏の平均年令 は $58 \mathrm{BY}$ の 55.1 歳から 59BY は 55.6 墄と0.5 歳の 上昇で，こちらも国勢調植結果同様に年々高㱓化が進ん でいる。

また，杜氏候補である杜氏補佐の平均年令は $58 \mathrm{BY}$ の 53.3 歳に封して $59 \mathrm{BY}$ は 53.8 歳と0.5 歳上昇し
ている。全従業員の平均年令は $58 \mathrm{BY}$ で 51.7 歳に対し て 59 BY は 52.1 歳と 0.4 歳の上昇である。

さらに 50 歳以上の酒造従業員は全体の $67 \%$, 杜氏だ けに限れば $83 \%$ といら高继訛の実態である。酒造従業 員の大半は出稼ぎ就労のため, 家族との別居や嫁対策等 により若年層に敬遠され, 従来のような出稼ぎ集団の編 成や後継者養成は, 最初の人材集めで苦労するといら現 況で亦る。

\section{2. 新潟県の出稼者の現況}

新潟県の代表的な出稼ぎ地带 $\mathrm{A}$ 地区と B地区の出稼者 名簿から職種別・人数別・平均年令及び度数分布等を調 ベてみた。

池鴆氏11の 57 BY 2 部落出稼者の調查は出稼者中の酒 造学務者がいずれも約 $5 \%$ といら低い地带についての 調查であるが，筆者はA地区は $53 \%$ B地区は $96 \%$ と 伝統的に酒造業への出稼ぎの多い地帯を調査対象として いる。第 1 表から, いずれの職種も平均年令は 50 歳以 上で, 特にボイラーマン及び焼いも屋は 60 歳, 若い方 は運送・配達業の 51 藏である。酒造工の平均年令をみ

第 1 表 $\mathrm{A}$ 地区出稼者 (昭和 60 年度 $\mathrm{A}$ 地区部落別出稼者名簿)

\begin{tabular}{|c|c|c|c|c|c|c|c|c|c|c|}
\hline & 食品製迭 & ボイラーマン & 酒 造 工 & 肥料弊造 & 一般荷役作業 & 土木・建設 & 通転手・速搬 & 部品製造 & 焼 W 8 & そ の 他 \\
\hline 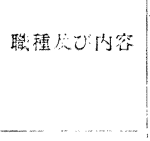 & 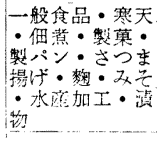 & 暖局補助 & & & 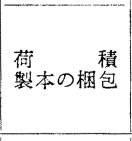 & $\begin{array}{l}\text { 左官・ガス } \\
\text { 舗装・建籁 } \\
\text { 土建 }\end{array}$ & 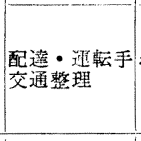 & 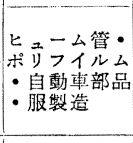 & & 染色・箱理人 \\
\hline 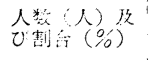 & $\begin{array}{c}68 \\
(13.7)\end{array}$ & $\left(\begin{array}{c}26 \\
5.2\end{array}\right)$ & $\begin{array}{c}262 \\
(53.0)\end{array}$ & $\begin{array}{c}10 \\
(2.0)\end{array}$ & $\begin{array}{c}37 \\
(7.4)\end{array}$ & $\left(\begin{array}{c}18 \\
(3.6)\end{array}\right.$ & $\begin{array}{c}28 \\
(5.6)\end{array}$ & $\left(\begin{array}{c}21 \\
4.2)\end{array}\right.$ & $\begin{array}{c}18 \\
(3.6)\end{array}$ & $\left(\begin{array}{c}9 \\
(1.8)\end{array}\right.$ \\
\hline 平均年令(藏) & 54.4 & 60.0 & 55.3 & 54.4 & 56.0 & 54.6 & 51.5 & 54.4 & 59.3 & \\
\hline 鼠 大 襍 & 75 & 71 & 75 & 59 & 74 & 63 & 71 & 63 & 70 & \\
\hline 最 小倠 & 34 & 47 & 33 & 52 & 44 & 43 & 40 & 36 & 48 & \\
\hline 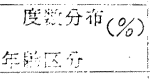 & & & & & & & & & & \\
\hline 40 觜末来落 & 2.9 & 0 & 0.8 & & 0 & 0 & 0 & 4.8 & 0 & \\
\hline $40 \sim 49$ & 17.6 & 7.7 & 17.6 & & 19.0 & 22.2 & 39.3 & 14.3 & 11.1 & \\
\hline $50 \sim 59$ & 61.8 & 42.3 & 53.4 & 100 & 57.0 & 55.6 & 50.0 & 61.9 & 44.5 & \\
\hline $60 \sim 69$ & 16.2 & 42.3 & 27.1 & & 19.0 & 22.2 & 7.1 & 19.0 & 33.3 & \\
\hline $70 \sim$ & 1.5 & 7.7 & 1.1 & & 5.0 & 0 & 3.6 & 0 & 11.1 & \\
\hline
\end{tabular}


第 2 表

\begin{tabular}{|c|c|c|c|}
\hline & B地区（人） & 新 潟 県2) & 関 信 局 ${ }^{22}$ \\
\hline 地 区 別 & $\begin{array}{l}\text { 酒造工 (346) } \\
\text { 土 建 ( } 6) \\
\text { 食 品 ( } 3) \\
\text { その他 ( } 5)\end{array}$ & & \\
\hline 平均年令（歳） & - & 48.6 & 51.4 \\
\hline 最 大 值 & - & 65 & 67 \\
\hline 最 小 值 & - & 31 & 31 \\
\hline 年 度数分布 $(\%$ & & & \\
\hline $\begin{array}{c}40 \text { 歳 } 末 \text { 満 } \\
40 \sim 49 \\
50 \sim 59 \\
60 \sim\end{array}$ & $\begin{array}{r}4.0 \\
18.9 \\
61.4 \\
15.8\end{array}$ & $\begin{array}{r}5.8 \\
47.2 \\
47.0\end{array}$ & $\begin{array}{r}2.1 \\
29.7 \\
68.2\end{array}$ \\
\hline
\end{tabular}

ると，A地区は 55.3 歳となっており，日杜連や第 2 表 の関信局の全従業員の平均年齢より $3 \sim 4$ 歳高い。

また，年令の度数分布をみると，いずれの職種も 40 歳未満はほとんど 0 である。40 歳代は運転・運送業や 一般荷役作業には多く見られるが，他業種はいずれも 20\% 以下である。どの業種も50６0 歳代が 70 ～80\% 以上を占めている。関信局の蔵人平均年龄は 51.4 歳, 50 歳未満が $32 \%$ である。特に出稼ぎ菲出の新潟県内の 蔵人を見ると, 平均年齢は 48.6 歳と低く, 50 筬未満は $53 \%$ 之高く, 自県内なら労力調達にまだ若手の 余裕が みられる。しかし, 上越新幹線, 関越及び北陸自動車の 開通は新潟県の出稼ぎ自体のイメージを大きく変えたで あろらと考光られる。

\section{3. 今後の対策}

季節産業であり, 中小企業メーカーの多い酒造業界の 大半は, 従来の季節出稼き酒造従業員の方が都合のよい 面もあるが，伝統的な出稼ぎ地域の未開拓分野の開発や 潜在化している酒造従業員の掘りおこしだけで現状を打 開して行くといら考光では，遅かれ早かれ後継者が漂と んぞいなくなってしまうであるう。そこで対策としては 次のことが考えられる。

(1) 大手メーカー向きの醸造機械は完備してきている が，中小メーカー向きの稼動期間の少ない醸造機械の開 発が遅机ているので, この方面の早急な研究開発が望ま れる。しかし，問題は人材であり，各社自から杜氏や三 役クラスの技能後継者を育てる積極的な姿勢が必要で西
第 3 表 吉川高校生の就職先

\begin{tabular}{|c|c|}
\hline 卒業生 総 数 & $890($ 名 $)$ \\
\hline 酒類 関 係 & 260 \\
\hline 調味食品関係 & 90 \\
\hline 慗菜 関 係 & 45 \\
\hline 一般食品製造関係 & 156 \\
\hline 試 験 研 究 機関 & 12 \\
\hline そ の 他 & 337 \\
\hline
\end{tabular}

1959年（1 回生) 1985（27回生）

る。

(2) 現在日本㳊一の基礎的な職業教育を行っている

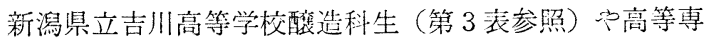
門教育を行っている東京農業大学醸造科生等を積極的に 活用する。

(3) 杜氏や三役が健在中に, 地元の青年や女社を採用 し，通勤制度や年間雇用制度を尊入し，製造，びん詰， 販売，事務等までもできるよらな多能化教育を行い，長 期間に渡って専門の技能管理者を坠成する。また技能労

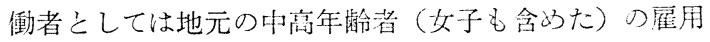
を促進する。

(4) 年間雇用の若い酒造従業員圶国や県の酾造機関て 技能教育をさせ, 相当の資格を与光て次代の技術幹部後 継者を養成する（中央会主催, 技術幹部養成基䃈研修汇 積極的治参加)。

(5) 小メーカーは酒造りの期間を調整して社氏や三役 クラスの技能者をかけもちさせる。または家族学働力の 活用をはかる。

以上，直台に解決できるものではなく，長期展望をた

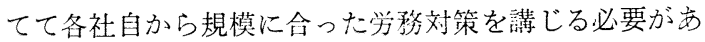
ろう。

（東京国税局鑑定官室）

最後に，ご校閲賜わりました井上博鑑定官公長に街 辞を申し上げます。

\section{文献}

1）酽造論文集第 38 号 (1983)

2) 関東信越国税局: 昭和 59 酒造年度酒税概況

3）日本酒造組合中央会：「清酒製造業汇於ける学務 の近代化方策」昭和 40 年 6 月

4）武藤 浩：酒造工肓成の急務，醇協 77 (1) 7 (1982)

5）三吉和重：酒造労務の現状と刘応，䁔協 $78(4)$ 232 (1983) 